\title{
In This Issue. . .
}

International Politics has a penchant for issues that defy boundaries and disciplines. We're not against either. But, we think that the stuff of international politics now lies well outside the constraints of territory or any single academic department or profession. It is no surprise, then, that we seek to publish the best among studies that examine problems with universal effects and that embody insights drawn from a variety of intellectual approaches.

Volume 38, Number 4 (December 2001) of International Politics is, in that regard, a treasure trove; in this issue, we offer studies about nuclear power safety, a post-Westphalian notion of popular sovereignty, religion and intervention, globalization and domestic nationalism, and privatization. Europe, Asia and Latin America may be geographic focal points for several articles - but the issues are transnational and the problems are global.

At the crux of these articles are topics that defy description or explanation based on states, power and national interests. The safety of nuclear power plants is a matter of global concern and defies efforts by states (or associations of states) to apply rigorous conditions that make certain memberships or benefits dependent on enhanced operational standards or closure of dangerous facilities. Unilateral or multilateral interventions allegedly for democratic or humanitarian purposes, instead seem to be affected significantly by religious identity not national interests or states' power calculus. Sovereignty, no longer vested firmly in the Westphalian state, may not be ready for a transit to a notion of personal sovereignty since respect for intolerance and hierarchy abandons public reason. That we have moved beyond authority over people within a territory as the sole criterion of sovereignty, however, is certain.

Further, we see in this issue that nationalism, rather than arising from within and based upon an application of military power, may increasingly be generated by globalization and its perceived threats and expressed through multilateral and global avenues. Privatization, we also learn, depends less on the efficacy of policy than citizen perception of public well-being.

John Van Oudenaren (European Division, US Library of Congress) carefully examines several cases in which Soviet-era nuclear power plants continue to operate despite European Union and international concern. Efforts to use leverage to insist on safety enhancements or plant closure - conditionality - means offering inducements for compliance and denial of such benefits for lack of compliance. Lithuania, Slovakia and Bulgaria - plus a shorter comment on Ukraine-demonstrate the limits of conditionality and absence of fungible state (or multilateral) power to insist that international safety standards be met. After more than a dozen years of post-Cold War multilateral engagement in nuclear safety issues (motivated by Chernobyl, of course, and frightening assessments of similar reactors in Bulgaria and elsewhere), 
reluctant, tardy and minimal compliance seems the norm. Countries' politicians try to hedge, feign and bob and weave - seeing to preserve such behemoths of the past. For what reason? International conditionalities - making progress towards EU membership or other benefits contingent on safety measures or plant closure are trumped by local politics. Concerns about unemployment, higher energy prices, and lower living standards are stronger influences on national legislatures and policy-makers than Brussels' or Transatlantic admonitions.

John Rawls, whose works are among the building blocks of 20th century political theory, is met head-on by David Fagelson (American University). Journals devoted to international relations, broadly construed, rarely tackle Rawls, whose writings "belong" to normative theory, not to IR. But, Fagelson recognizes that Rawls' efforts to construct a "law of peoples" to replace Westphalian sovereignty vested in the nation-state is flawed. To Fagelson, Rawls' requirement that liberal peoples accept both intolerance and hierarchy means that governance based on a "law of the peoples" is unlikely to be realized. When the World Bank or US Agency for International Development (USAID) provide assistance, they typically require legal or political reforms. Rawls wouldn't, because such conditions violate rights of self-determination and indigenous beliefs. If post-Westphalian sovereignty is to be found "below," says Fagelson, it cannot be by abandoning normative expectations; popular sovereignty does not connote accepting the unacceptable.

Believing and intervening, i.e., the link between religious identity and unilateral or multilateral intervention, is explored by Jonathan Fox (Bar Ilan University). While states' leaders would have us believe that interventions are mounted to protect national interests or, increasingly, to provide humanitarian relief, Fox sees that religious affinities with minority groups are associated with the likelihood of intervention. The dyad of Christian and Moslems, for example, is many times more likely to lead to intervention by NGOs, multilateral organizations and states than are conflicts between or among other groups. Were we to labor under the assumption that humanitarian concerns or raw power interests (e.g., energy) acted alone to produce intervention, Fox says "think again." And, we think readers will do just that after considering his argument and data.

Japan and globalization are a strange couple. While the common assumption might well be that globalization, for all that it implies about transnational integrative trends, will mitigate nationalism, William $\mathbf{H}$. Thornton (National Cheng Kung University) argues forcefully that the national consequences of global change in Japan are the promotion and encouragement of a "reactionary globalization." This bold essay offers a provocative thesis. Right or wrong, Thornton evocatively points to globalization's downsides - particularly in a country and society with reason to be concerned about recent limits to prosperity and challenges to its economic supremacy. One does not have to look too far into recent Japanese political trends to wonder if Thornton may not be, at least partially, correct.

In this issue, our fifth article is one that has appeared in International Politics before (Vol. 38, No. 2, June 2001). We have reprinted Charles L. Davis and Kenneth Coleman's excellent article on privatization in Latin Amer$i c a$ in this issue because of an error that appeared in its first printing. Kluwer 
In this issue... vii

Publishers offers their apologies to the authors and readers for the original misprint.

More pleasant is this issue's reviews, including two major essays and a number of individual book reviews. Our Review Editors, Drs. Marijke Breuning and John Ishiyama (both of Truman State University) continue to fashion a section that features critical examinations of literature linking international relations, comparative politics, and other disciplines. Andrea Grove's look at several recent works on identity, and her contrast of the normative or visceral nature of such identity, is an important effort - implicitly tied to articles in this issue such as those by Fagelson, Fox and Thornton. Chris Scholl's essay takes on that growth industry of books on globalization, examining several that represent a wide-range of perspectives.

Continuing on a happier note, we will have the benefit of several new assistant editors for 2001-2002: Elizabeth George and Mark Hamilton at Miami University in Oxford, Ohio; Michael Spring at George Washington University in Washington, DC; and Jeremy Gray, John Hilton and Timothy Papuga at Truman State University, Kirksville, Missouri. 